\section{Pengaruh Koneksi Politik, Dewan Komisaris dan Karakteristik Perusahaan terhadap Penghindaran Pajak (Perusahaan BUMN Yang Terdaftar di Bursa Efek Indonesia)}

\author{
Anisa Nadia Hijriani, Sri Wahjuni Latifah, Setu Setyawan \\ Program Studi Akuntansi Fakultas Ekonomi dan Bisnis \\ Universitas Muhammadiyah Malang \\ Jl. Raya Tlogomas No.246 Malang
}

JRAK

\title{
ABSTRACT
}

The purpose of this research is to test whether politic connections commissioners and characteristic' companies can influence tax avoidance which is done by the companies. Object of this research is all of the BUMN companies from various sectors which are listed in Indonesian Stock Exchange 2011-2013. The data which is used is secondary data directly obtain from BEI website and each of companies website by using documentation technique. The data is analyzed by using double regression analysis method and hypotheses test. Based on the result of the test which is done in this research, it shows that all of independent variables do not influence toward the tax a voidance, either through Gaap ETR or Current ETR. With the t-test of political connections, the average attendance, Roa, DER and firm size have no effect on tax evasion as measured by ETR and Current ETR Gaults, but the number of board meetings negatively affects the tax evasion measured by Current ETR partially

Keywords: Political connection, commissioners, characteristic of companies, and tax evasion

\section{PENDAHULUAN}

Target penerimaan Negara dari pajak meningkat setiap tahunnya, hal ini dapat dilihat dari APBN pajak untuk tahun 2014 meningkat sebesar 16,4\% dari tahun lalu. Dengan demikian terlihat bahwa pajak memiliki peran penting sebagai sumber pendapatan Negara. Walaupun harapan pemerintah tinggi terhadap penerimaan pajak, target tersebut dalam 12 tahun belakangan tidak pernah tercapai (www.MedanBisnis.com). Ada beberapa indikasi kemungkinan kenapa target penerimaan pajak tidak tercapai. Kondisi ini diperkirakan karena banyaknya wajib pajak berupa perusahaan-perusahaan yang melakukan penghindaran pajak baik secara legal (tax avoidance) ataupun secara illegal (tax evasion).

Perusahaan yang melakukan penghindaran pajak tidak akan dikenai sanksi atau hukuman dari pemerintah, karena perusahaan berusaha mengurangi beban pajaknya dengan cara legal dan tidak melanggar undang-undang perpajakan yang berlaku (Reza, 2012). Fenomena wajib pajak yang mempunyai keinginan untuk tidak membayar pajak sama sekali atau membayar pajak dengan beban yang rendah dengan tidak melanggar Undang-Undang adalah sifat alamiah seorang manusia (Pohan, 2011).

Dari pernyataan-pernyataan diatas dapat ditarik kesimpulan bahwa adanya perbedaan kepentingan antara pemerintah dan perusahaan. Perbedaan kepentingan antara wajib pajak dan pemerintah dalam proses pelaksanaan pemungutan pajak, pemerintah melalui Direktorat Jendral Pajak (DJP), selalu berusaha untuk terus menaikkan penerimaan Negara dari sektor pajak, sementara wajib pajak berusaha untuk terus mengurangi beban pajak (Mulyani, dkk., 2014).

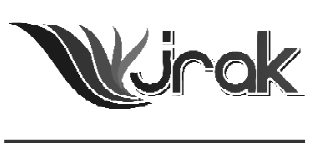

Jurnal Reviu Akuntansi dan Keuangan

ISSN: 2088-0685

Vol.4 No. 1, April 2014 Pp 525-534 


\section{Pengaruh Koneksi Politik...}

Perusahaan yang terdaftar di BEI tidak hanya dimiliki oleh swasta, tetapi juga pemerintah, mengingat ada perbedaan kepentingan antara wajib pajak dan pemerintah, menimbulkan indikasi adanya penghindaran pajak yang dilakukan oleh perusahaan tersebut. Pada tahun 2010 terdapat 16 perusahaan BUMN yang melakukan penunggakan pajak dan masih ada 2 perusahaan BUMN yang melakukan penunggakan pajak pada awal tahun 2015 (Fiskal.com dan Hukumonline.com). Penunggakan ini kemungkinan terjadi karena 4 hal dan salah satunya adalah penyebab lain yang harus diselidiki oleh BPK (Hukumonline.com). Kemungkinan lain perusahaan BUMN melakukan penghindaran pajak karena 10 BUMN termasuk dalam penyetor deviden terbanyak di tahun 2013 (detikfinance.com). Dari sini akan timbul pertanyaan apakah perusahaan BUMN yang seharusnya menjadi sumber penerimaan pajak Negara juga akan melakukan penghindaran pajak?

Selain itu, adanya campur tangan dari lingkungan yudikatif dan legislative dalam membayar pajak salah satu penyebab tunggakan pajak BUMN. Agus selaku Menteri Keuangan mengatakan, bahwa banyak wajib pajak dan pelaku ekonomi berusaha melindungi diri di lingkungan yudikatif (peradilan) dan legislatif (pembuat undang-undang atau DPR), bahkan penegak hukum yang terdiri atas kepolisian dan kejaksaan untuk menghindari membayar pajak. (kickdahlan.wordpress.com).

Setiap kebijakan-kebijakan yang diambil perusahaan termasuk dalam melakukan penghematan pajak, selalu di awasi oleh dewan komisaris dan semakin baiknya corporate governance akan meningkatkan manajemen pajak (Reza, 2012). Selain itu, sifat penghindaran pajak yang dilakukan dalam tata kelola perusahaan yang buruk di tambah lingkungan yang kompleks dan tidak jelas, memberikan kesempatan bagi manajer untuk mengalihkan sumberdaya perusahaan bagi keuntungan pribadinya (Desai \& Dharmapala, 2006)

Setiap perusahaan mempunyai ciri khas perusahaannya masing-masing, perusahaan besar cenderung akan melakukan perencanaan pajak untuk melakukan penghindaran pajak (Surbakti, 2012). Karakteristik perusahaan juga dapat memengaruhi variasi tariff pajak efektif antar perusahaan, seperti perusahaan yang melakukan pembiayaan lewat hutang akan menghasilkan pajak yang kecil (Brigham \& Houston, 2011).

Berdasarkan latar belakang diatas, peneliti ingin melihat pengaruh koneksi politik, dewan komisaris dan karakteristik perusahaan sebagai variabel independen terhadap penghindaran pajak sebagai variabel dependen. Dalam mengukur penghindaran pajak dapat dilakukan dengan beberapa cara, namun pada penelitian ini menggunakan ETR(effective tax rates) untuk mengukur seberapa besar kemungkinan perusahaan melakukan penghindaran pajak. ETR (effective tax rates) adalah cara yang digunakan untuk mengetahui seberapa besar potensi penghindaran pajak yang dilakukan perusahaan. ETR terbagi dua yaitu GAAP ETR (beban pajak dibagi pendapatan sebelum pajak) dan current ETR (beban pajak kini dibagi pendapatan sebelum pajak). Penggunaan ETR sesuai dengan penelitian terdahulu Reza (2012) dan Mulyani, dkk (2014), sehingga peneliti dapat mengajukan hipotesis berupa:

$\mathrm{H}_{1}$ : Koneksi politik berpengaruh negatif terhadap penghindaran pajak

$\mathrm{H}_{2}$ : Jumlah rapat dewan komisaris berpengaruh negatif terhadap peng-hindara pajak.

$\mathrm{H}_{3}$ : Tingkat kehadiran anggota dewan komisaris dalam rapat berpengaruh negatif terhadap penghindaran pajak.

$\mathrm{H}_{4}: \quad R O A$ berpengaruh negatif terhadap penghindaran pajak.

$\mathrm{H}_{5}$ : Leverage berpengaruh positif terhadap penghindaran pajak.

$\mathrm{H}_{6}$ : Ukuran perusahaan berpengaruh positif terhadap penghindaran pajak. 
Sampel penelitian ini dilakukan pada perusahaan BUMN yang terdaftar di BEI, dengan objek penelitian yang berbeda dari penelitian-penelitian sebelumnya, diharapkan penelitian ini dapat menggambarkan bagaimana perlakuan perusahaan BUMN terhadap penghindaran pajak. Pemilihan perusahaan BUMN juga di dasari data yang diperoleh dari SahamOk.com, dimana perusahaan tidak dibatasi oleh sektor-sektor tertentu.

\section{METODE PENELITIAN}

Penelitian ini merupakan penelitian asosiatif dengan mengambil objek penelitian berupa seluruh perusahaan BUMN dari berbagai sektor yang terdapat dalam Bursa Efek Indonesia tahun 2011-2013 (www.idx.co.id) yang diklasifikasikan oleh SahamOk.com. Pengambilan sampel dalam penelitian ini menggunakan metode purporsive sampling. Data yang digunakan dalam penelitian adalah data sekunder berupa laporan tahunan dan laporan keuangan dari perusahaan BUMN, diperoleh secara langsung dari website BEI yaitu $w w w . i d x . c o . i d$ dan website masing-masing perusahaan dengan teknik dokumentasi.

Analisis data dilakukan dengan tahapan sebagai berikut:

Statistic Descriptive. Uji ini dilakukan untuk memberikan gambaran atau deskripsi suatu data dari sampel penelitian yang dilihat dari nilai rata-rata (mean), standar deviasi, maksimum dan minimum. Kemudian dilanjutkan dengan Uji Asumsi Klasik. Dalam uji asumsi klasik terdapat beberapa tahap pengujian, yaitu: uji normalitas, uji heterokedasitas, uji multikollinieritas, dan uji autokorelasi. Pada tahapan terakhir dilakukan pengujian hipotesis yaitu dengan melakukan uji $\mathrm{F}$, uji determinan, dan uji t.

\section{HASIL DAN PEMBAHASAN}

Populasi dalam penelitian ini adalah perusahaan BUMN dari seluruh sektor industri tahun 2011-2013 yang sudah diklasifikasikan oleh SahamOk.com. Dari semua perusahaan tersebut yang memenuhi kriteria sampel hanya 10 perusahaan pertahunnya. Data penelitian ini diperoleh dari laporan tahunan dan laporan keuangan perusahaan. Sampel pada penelitian ini ditentukan menggunakan purposive sampling.

Hasil uji statistik deskriptif

\begin{tabular}{lrrrrrr}
\hline & N & Minimum & Maximum & Mean & $\begin{array}{c}\text { Std. } \\
\text { Deviation }\end{array}$ & Variance \\
\hline Roa & 30 & .019 & .806 & .09506 & .146208 & .021 \\
KP & 30 & 0 & 1 & .10 & .305 & .093 \\
CurrentET & 30 & .000 & .496 & .22575 & .123632 & .015 \\
GaapETR & 30 & .196 & .496 & .29340 & .094900 & .009 \\
attend & 30 & .238 & 1.000 & .78596 & .156945 & .025 \\
Der & 30 & .345 & 8.432 & 3.75844 & 2.885150 & 8.324 \\
Meet & 30 & 3 & 47 & 19.83 & 12.766 & 162.971 \\
Size & 30 & 20.128 & 34.228 & 29.95802 & 3.785140 & 14.327 \\
Valid N & 30 & & & & & \\
\hline
\end{tabular}

Tabel 1

Kriteria

Pengambilan Sampel

Dari tabel di atas dapat diketahui bahwa jumlah sampel atau $\mathrm{N}$ data valid (Valid N) yang akan diteliti berjumlah 30 sampel. 
Pengaruh

Koneksi

Politik...

528

Gambar 1.1

Uji Normalitas DataGaap ETR

Gambar 1.2

Uji Normalitas Data Current ETR
Hasil uji asumsi klasik

Gambar 1. Uji normalitas

Normal P.P Plot of Regression Standardized Residual

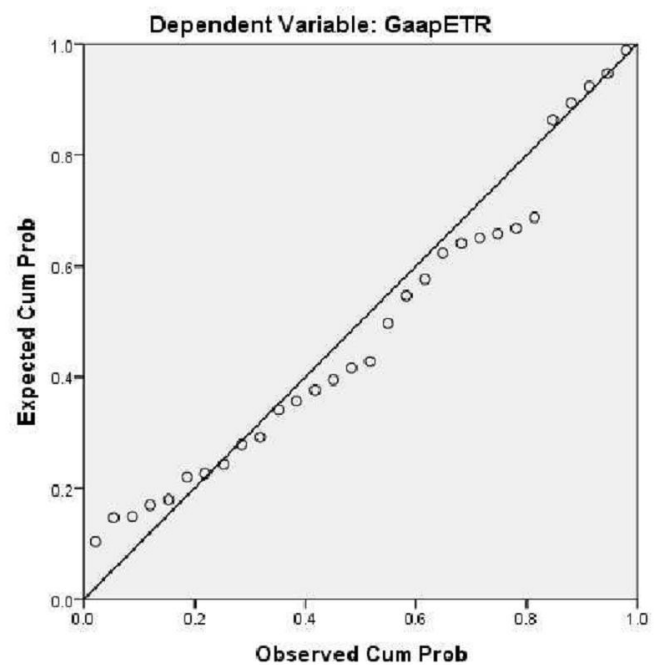

Normal P-P Plot of Regression Standardized Residual

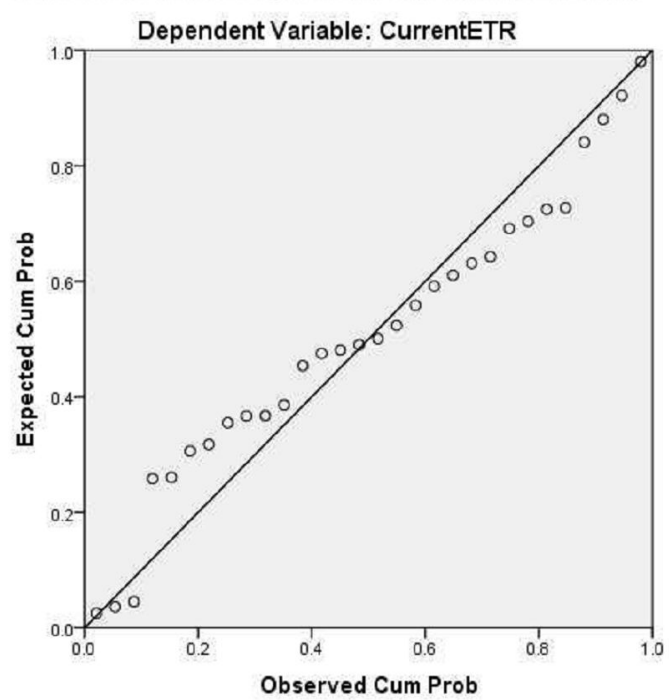

Dapat dilihat dari gambar diatas bahwa titik-titik mengikuti dan mendekati garis diagonalnya sehingga dapat disimpulkan bahwa regresi memenuhi uji asumsi normalitas. Sehingga model regresi layak dipakai untuk penghindaran pajak dengan proksi Gaap ETR dan Current ETR berdasarkan variabel independennya.

Gambar 2. Uji heterokedasitas

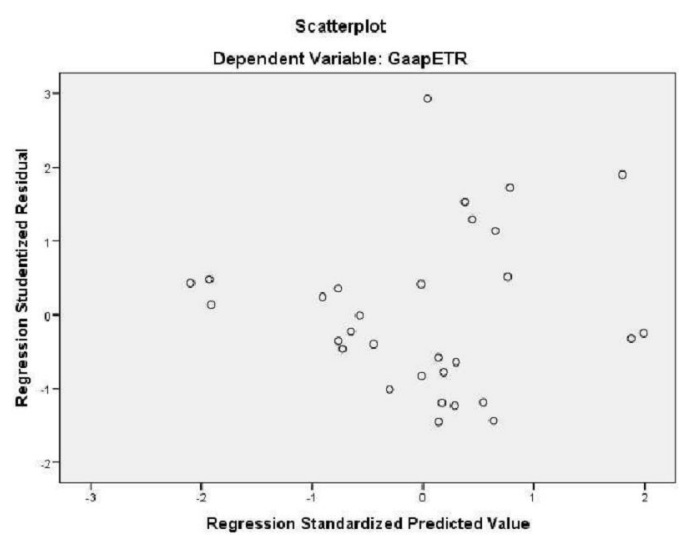




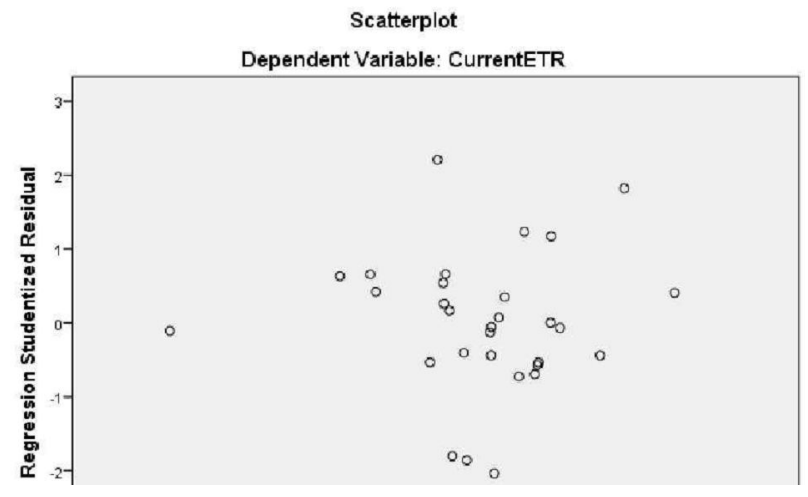

JRAK

Gambar 2.2 Uji

Heteroskedastisitas Current ETR

Dari gambar diatas dapat disimpulkan bahwa tidak terjadi masalah heteroskedastisitas dalam model regresi untuk Gaap ETR.

Tabel 2. Uji multikollinieritas

\begin{tabular}{|c|c|c|c|c|c|c|c|}
\hline \multirow{2}{*}{ Model } & \multicolumn{2}{|c|}{$\begin{array}{l}\text { Unstandardized } \\
\text { Coefficients }\end{array}$} & \multirow{2}{*}{$\begin{array}{c}\begin{array}{c}\text { Standardized } \\
\text { Coefficients }\end{array} \\
\text { Beta }\end{array}$} & \multirow{2}{*}{$\mathrm{t}$} & \multirow{2}{*}{ Sig. } & \multicolumn{2}{|c|}{ Collinearity Statistics } \\
\hline & B & $\begin{array}{l}\text { Std. } \\
\text { Error }\end{array}$ & & & & Tolerance & VIF \\
\hline (Constant) & .561 & .152 & & 3.699 & .001 & & \\
\hline $\mathrm{KP}$ & -.042 & .060 & -.134 & -.694 & .495 & .794 & 1.259 \\
\hline Meet & -.004 & .002 & -.520 & -2.394 & .026 & .629 & 1.589 \\
\hline 1 attend & .016 & .126 & .026 & .124 & .903 & .681 & 1.469 \\
\hline Roa & .100 & .123 & .153 & .811 & .426 & .831 & 1.204 \\
\hline Der & .007 & .007 & .227 & 1.047 & .307 & .631 & 1.586 \\
\hline Size & -.008 & .005 & -.311 & -1.644 & .114 & .833 & 1.201 \\
\hline Dummy Tahun & -.009 & .037 & -.046 & -.250 & .805 & .869 & 1.151 \\
\hline \multirow{2}{*}{ Model } & \multicolumn{2}{|c|}{$\begin{array}{l}\text { Unstandardized } \\
\text { Coefficients }\end{array}$} & $\begin{array}{l}\text { Standardized } \\
\text { Coefficients }\end{array}$ & \multirow[t]{2}{*}{$\mathrm{t}$} & \multirow{2}{*}{ Sig. } & \multicolumn{2}{|c|}{ Collinearity Statistics } \\
\hline & B & Std. Error & Beta & & & Toleranc e & VIF \\
\hline (Constant) & .544 & .206 & & 2.642 & .015 & & \\
\hline KP & .000 & .082 & -.001 & -.005 & .996 & .794 & 1.259 \\
\hline Meet & -.002 & .002 & -.235 & -1.039 & .310 & .629 & 1.589 \\
\hline attend & -.151 & .172 & -.192 & -.881 & .388 & .681 & 1.469 \\
\hline 1 Roa & -.385 & .167 & -.455 & -2.311 & .031 & .831 & 1.204 \\
\hline Der & -.010 & .010 & -.226 & -1.000 & .328 & .631 & 1.586 \\
\hline Size & -.003 & .006 & -.106 & -.539 & .595 & .833 & 1.201 \\
\hline Dummy Tahun & .068 & .050 & .265 & 1.376 & .183 & .869 & 1.151 \\
\hline
\end{tabular}

Table 2.1

Uji Multikolinieritas Gaap ETR

Pada dua table di atas dapat disimpulkan bahwa semua variabel independen dengan dua proksi penghindaran pajak mempunyai VIF kurang dari 10 dan nominal tolerance lebih dari 0,10 . Hasil tersebut menunjukkan bahwa model regresi tidak terjadi multikolinieritas.

Tabel 3. Uji Autokolerasi

\begin{tabular}{lc}
\hline & Unstandardized Residual \\
\hline Test Value $^{\mathrm{a}}$ & -.01734 \\
Cases $<$ Test Value & 15 \\
Cases $>=$ Test Value & 15 \\
Total Cases & 30 \\
Number of Runs & 13 \\
Z & -.929 \\
Asymp. Sig. (2-tailed) & .353 \\
\hline
\end{tabular}

Tabel 3.1

Run Test Gaap ETR 


\section{Pengaruh Koneksi Politik...} 530

Tabel 3.2 Run Test Current ETR
Tabel 4.1

Uji Determinasi

Gaap ETR Model Summary ${ }^{\mathrm{b}}$

$\underline{\text { Runs Test }}$

\begin{tabular}{lc} 
& Unstandardized Residual \\
\hline Test Value $^{3}$ & -.00140 \\
Cases < Test Value & 15 \\
Cases $>=$ Test Value & 15 \\
Total Cases & 30 \\
Number of Runs & 21 \\
Z & 1.672 \\
Asymp. Sig. (2-tailed) & .094 \\
\hline
\end{tabular}
a. Median

Hasil run test menunjukkan bahwa asymp. Sig (2-tailed) Gaap ETR dan Current ETR memiliki nilai lebih besar dari 0,05 dengan demikian data yang digunakan cukup random sehingga tidak terdapat masalah autokorelasi pada data yang di uji.

Hasil Pengujian Hipotesis

Tabel 4. Uji Determinan

Model Summary ${ }^{\mathrm{b}}$

\begin{tabular}{ccccc} 
Model & $\mathbf{R}$ & R Square & Adjusted R Square & $\begin{array}{c}\text { Std. Error of the } \\
\text { Estimate }\end{array}$ \\
\hline 1 & $.589^{\mathrm{a}}$ & .346 & .138 & .088090 \\
\hline
\end{tabular}

a. Predictors: (Constant), DummyTahun, KP, Meet, Size, Roa, attend, Der

b. Dependent Variable: GaapETR

Dari table diatas dapat diketahui bahwa $\mathrm{R}$ square atau koefisien determinasinya 0,346 (berasal dari $0,589 x$ 0,589). Hal ini menunjukkan variabel independen dalam penelitian ini menerangkan variabel dependennya yang di proksikan dengan Gaap ETR sebesar 34,6\% dan sisanya dijelaskan oleh faktor lain seperti cost of debt, komite audit, karakter eksekutif, kepemilikan saham mayoritas dan minoritas.

Model Summary ${ }^{\mathrm{b}}$

Tabel 4.2

Uji Determinasi Current ETR
Tabel 5.1 Uji-F GaapETR $\mathrm{ANOVA}^{\mathrm{a}}$

\begin{tabular}{ccccc}
\hline Model & $\mathbf{R}$ & R Square & Adjusted R & Std. Error of the \\
\hline & & Square & Estimate \\
& & 290 & .064 & .119612 \\
& & & \\
\hline
\end{tabular}

Dari table diatas dapat diketahui bahwa $\mathrm{R}$ square atau koefisien determinasinya 0,290 (berasal dari $0,538 x$ 0,538). Hal ini menunjukkan variabel independen dalam penelitian ini menerangkan variabel dependennya yang di proksikan dengan Current ETR sebesar 29\% dan sisanya dijelaskan oleh faktor lain seperti cost of $d e b t$, komite audit, karakter eksekutif, kepemilikan saham mayoritas dan minoritas.

Tabel 5. Uji F

\begin{tabular}{lrrrrr}
\hline \multicolumn{1}{c}{ Model } & Sum of Squares & Df & Mean Square & F & Sig. \\
\hline Regression & .129 & 7 & .018 & 1.283 & $.304^{\mathrm{b}}$ \\
1 Residual & .315 & 22 & .014 & & \\
Total & .443 & 29 & & & \\
\hline
\end{tabular}


Dari uji tersebut dapat dilihat bahwa hasil uji-F yang telah dilakukan mempunyai signifikansi atau probabilitasnya sebesar 0,304. Dengan demikian dapat disimpulkan bahwa nilai tersebut lebih besar dari 0,05 sehingga H0 diterima, maka variable independen saat diuji secara simultan tidak mempunyai pengaruh terhadap penghindaran pajak dengan proksi Gaap ETR.

\begin{tabular}{lrrrrr}
\hline Model & Sum of Squares & Df & Mean Square & F & Sig. \\
\hline Regression & .090 & 7 & .013 & 1.665 & $.170^{\mathrm{b}}$ \\
1 Residual & .171 & 22 & .008 & & \\
Total & .261 & 29 & & & \\
\hline
\end{tabular}

JRAK

Tabel 5.2

Uji-F Current ETR ANOVA $^{a}$

Dari uji tersebut dapat dilihat bahwa hasil uji-F yang telah dilakukan mempunyai signifikansi atau probabilitasnya sebesar 0,170 . Dengan demikian dapat disimpulkan bahwa nilai tersebut lebih besar dari 0,05 sehingga H0 diterima. Dengan t table 3,35 maka t hitung $<\mathrm{t}$ table, maka variable independen saat diuji secara simultan tidak mempunyai pengaruh terhadap penghindaran pajak dengan proksi Current ETR.

Tabel 6. Uji t

\begin{tabular}{|c|c|c|c|c|c|c|}
\hline & \multirow[t]{2}{*}{ Model } & \multicolumn{2}{|c|}{$\begin{array}{c}\text { Unstandardized } \\
\text { Coefficients }\end{array}$} & \multirow{2}{*}{$\begin{array}{c}\begin{array}{c}\text { Standardized } \\
\text { Coefficients }\end{array} \\
\text { Beta }\end{array}$} & \multirow[t]{2}{*}{$\mathrm{t}$} & \multirow[t]{2}{*}{ Sig. } \\
\hline & & B & Std. Error & & & \\
\hline \multirow{8}{*}{1} & (Constant) & .561 & .152 & & 3.699 & .001 \\
\hline & $\mathrm{KP}$ & -.042 & .060 & -.134 & -.694 & .495 \\
\hline & Meet & -.004 & .002 & -.520 & -2.394 & .026 \\
\hline & Attend & .016 & .126 & .026 & .124 & .903 \\
\hline & Roa & .100 & .123 & .153 & .811 & .426 \\
\hline & Der & .007 & .007 & .227 & 1.047 & .307 \\
\hline & Size & -.008 & .005 & -.311 & -1.644 & .114 \\
\hline & DummyTahun & -.009 & .037 & -.046 & -.250 & .805 \\
\hline
\end{tabular}

Tabel 6.1

Uji Parsial Gaap ETR

\begin{tabular}{|c|c|c|c|c|c|c|}
\hline & \multirow[t]{2}{*}{ Model } & \multicolumn{2}{|c|}{$\begin{array}{l}\text { Unstandardized } \\
\text { Coefficients }\end{array}$} & \multirow{2}{*}{$\begin{array}{c}\begin{array}{c}\text { Standardized } \\
\text { Coefficients }\end{array} \\
\text { Beta }\end{array}$} & \multirow[t]{2}{*}{$\mathrm{t}$} & \multirow[t]{2}{*}{ Sig. } \\
\hline & & B & Std. Error & & & \\
\hline \multirow{9}{*}{1} & (Constant) & & & & & \\
\hline & & .544 .000 & .206 .082 & & $2.642-.005$ & .015 .996 \\
\hline & $\mathrm{KP}$ & & & -.001 & & \\
\hline & Meet & -.002 & .002 & -.235 & -1.039 & .310 \\
\hline & Attend & -.151 & .172 & -.192 & -.881 & .388 \\
\hline & Roa & -.385 & .167 & -.455 & -2.311 & .031 \\
\hline & Der & -.010 & .010 & -.226 & -1.000 & .328 \\
\hline & Size & -.003 & .006 & -.106 & -.539 & .595 \\
\hline & DummyTahun & .068 & .050 & .265 & 1.376 & .183 \\
\hline
\end{tabular}

Tabel 6.2

Uji Parsial Current ETR

Dari tabel uji parsial dapat diketahui bahwa hasil pengujian yang dilakukan dalam peneitian ini menunjukkan bahwa seluruh variabel independen tidak berpengaruh secara bersama-sama terhadap penghindara pajak baik melaui Gaap ETR ataupun Current ETR yang dilihat dari nilai signifikasi masing-masing variabel $>0.05$. Dengan uji-t koneksi politik, rata-rata kehadiran, Roa, DER dan ukuran perusahaan tidak memilik pengaruh terhadap penghindaran pajak yang 


\section{Pengaruh Koneksi Politik...}

diukur melalui Gaap ETR dan Current ETR, namun jumlah rapat dewan komisaris berpengaruh negative terhadap penghindaran pajak yang diukur melalui $\mathrm{Cur}^{-}$ rent $E T R$ secara parsial.

\section{Pembahasan:}

Dalam penelitian ini koneksi politik, dewan komisaris dan karakteristik perusahaan saat di uji-F tidak memiliki pengaruh secara simultan terhadap penghindaran pajak yang di proksikan melalui Gaap ETR dan Current ETR. Berdasarkan perhitungan statistik menggunakan uji-t menunjukkan bahwa masing-masing variabel independen tidak memliki pengaruh untuk kedua proksi penghindaran pajak. Namun variabel Roa memiliki pengaruh negative secara parsial sesuai dengan Maharani \& Syardana (2014) yang menyatakan Roamemiki pengaruh negatif terhadap penghindaran pajak. Tidak berpengaruhnya variabel dependen secara simultan ataupun parsial dikarenakan perusahaan BUMN merupakan perusahaan yang dimiliki Negara, sehingga lebih diawasi oleh Negara. Selain itu, pada tahun penelitian beberapa perusahaan BUMN sedang siawasi oleh BPK karena penunggakan pajak.

Hasil koneksi politik tidak berpengaruh terhadap penghindaran pajak dengan proksi Gaap ETR dan Current ETR, hasil ini tidak sesuai dengan Mulyani (2014) dan yang menyatakan bahwa koneksi politik berpengaruh negative terhadap penghindaran pajak. Hal ini dikarenakan pada penelitian ini hanya terdapat satu perusahaan yang diberikan nilai 1 berdasarkan variabel dummy, berbeda dengan penelitian sebelumnya sehingga terdapat perbedaan antara penelitian sekarang dengan peneliti terdahulu.

Rata-rata tingkat kehadiran dewan komisaris tidak memiliki pengaruh terhadap penghidaran pajak dalam proksi Gaap ETR dan hasil ini sesuai dengan Reza (2012) yang menyatakan bahwa rata-rata tingkat kehadiran dewan komisaris tidak berpengaruh terhadap penghindaran pajak.

Size memiliki hasil yang berbeda dengan penelitian sebelumnya Puspita (2014) yang menyatakan bahwa ukuran perusahaan memiliki pengaruh yang positif namun tidak signifikan. Namun hal ini sesuai dengan Rusydi (2013) yang menyatakan ukuran perusahaan tidak berpengaruh terhadap tingkat keagresifan penghindaran pajak.

$D E R$ dengan hasil tidak berpengaruh berbeda dengan Mulyani, dkk (2014) yang menyatakan bahwa utang mempunyai pengaruh positif signifikan. Namun hal ini sesuai dengan Darmawan (2014) yang menyatakan rasio lavarage tidak memiliki pengaruh terhadap penghindaran pajak.

\section{KESIMPULAN}

Tujuan dari penelitian ini adalah untuk menguji apakah koneksi politik, dewan komisaris dan karakteristik perusahaan mempengaruhi penghindaran pajak yang dilakukan oleh perusahaan, cara yang digunakan untuk menghindari pajak tersebut dilakukan secara legal dan tidak melanggar undang-undang. Penelitian ini menggunakan sampel berupa seluruh perusahaan BUMN yang terdaftar d BEI yang telah memenuhi kriteria dalam melakukan penelitian ini, sehingga jumlah sampel yang di dapat adalah sebanyak 30 perusahaan dalam periode 3 tahun dari 90 perusahaan.

Berdasarkan hasil pengujian yang dilakukan dalam peneitian ini menunjukkan bahwa seluruh variabel independen tidak berpengaruh secara bersamasama terhadap penghindara pajak baik melaui Gaap ETR ataupun Current ETR. Dengan uji-t koneksi politik, rata-rata kehadiran, Roa, DER dan ukuran perusahaan tidak memilik pengaruh terhadap penghindaran pajak yang diukur melalui Gaap ETR dan Current ETR, namun jumlah rapat dewan komisaris berpengaruh 
negative terhadap penghindaran pajak yang diukur melalui Current ETR secara parsial.

Pada penelitian ini penghitungan penghindaran pajak hanya dengan melihat perbandingan Gaap ETR dan Current ETR tanpa bisa melihat keterkaitan kedua penghitungan sehingga diharapkan untuk peneliti selanjutnya untuk mengkaji lebih dalam lagi mengenai keterkaitan kedua perhitungan tersebut.

\section{DAFTAR PUSTAKA}

a. Referensi dari Buku

Brigham, Eugene F. dan Joel F. Hpuston. Dasar-Dasar Manajemen Keuangan Buku 2 Edisi 11. 2011. Jakarta: Salemba Empat.

Pohan, Chairil Anwar. 2011. Optimizing Corporate Tax Management: KajianPerpajakan dan Tax Palnningnya Terkini. Bumi Aksara.

b. Referensi dari jurnal, majalah, koran, dsb.

Desai, Mihir A., and D. Dharmapala. 2004. Corporate Tax Avoidance and High Powered Incentives. Working Paper Series 2004-09: University of Connecticut.

d. Referensi dari prosiding, thesis, disertasi, paper (unpublished)

Mulyani, Sri, Darminto dan M. G Wi Endang N.P. 2014. Pengaruh Karakteristik Perusahaan, Koneksi Politik dan Reformasi Perpajakan Terhadap Penghindaran Pajak (Studi Pada Perusahaan Manufaktur Yang Terdaftar di Bursa Efek Indonesia Tahun 2008-2012). Skripsi: Universitas Brawijaya.

Reza, Faisal. Pengaruh Dewan Komisaris dan Komite Audit Terhadap Penghindaran Pajak. 2012. Skripsi: Universitas Indonesia. 
